\section{Environmental Benefits of Wireless Sensor-based Irrigation Networks: Case-study Projections and Potential Adoption Rates}

\author{
John C. Majsztrik ${ }^{1,3}$, Elizabeth W. Price ${ }^{2}$, and Dennis M. King ${ }^{2}$
}

ADDITIONAL INDEX WORDS. public benefits, nutrient, water and carbon reduction, Chesapeake Bay, technology adoption, precision irrigation, specialty crops

SUMMARY. We describe and estimate the potential environmental benefits associated with the adoption of wireless sensor irrigation networks (WSIN) in United States ornamental crop production. Benefit estimates are based on results from on-farm research conducted during the previous three years, using both conservative and optimistic assumptions about the levels of WSIN technology adoption. We project reductions in water use and air and water emissions for six U.S. agricultural regions, the U.S. overall, and the six states that make up the Chesapeake Bay watershed. Based on these analyses, an average nationwide WSIN adoption rate of $50 \%$ in ornamental operations would result in annual water use savings of $\approx \mathbf{2 2 3}$ billion liters (enough for 400,000 U.S. households annually) or a $25 \%$ reduction in total water use for all ornamental production. Reductions in annual carbon dioxide emissions, assuming only the reduced energy use from pumping less water was $36,232 \mathrm{Mg}$ (equivalent to removing 7500 cars annually). Reduced fertilizer applications and more efficient irrigation resulted in reductions of $282,000 \mathrm{~kg}$ nitrogen and 182,000 $\mathrm{kg}$ phosphorous. These efficiency gains and nutrient discharge reductions have been shown to generate significant profits for growers, but would cost hundreds of thousands of dollars to achieve using conventional urban or agricultural best management practices (BMPs). If WSIN technologies are adopted in other areas of specialty horticulture (e.g., fruit, vegetable, and nut production) or in agronomic crops [e.g., corn (Zea mays) and wheat (Triticum sp.)], the indirect and induced private and environmental benefits will likely be much higher. Since the environmental benefits of WSIN technologies depend critically on adoption rates, we also briefly describe potential pathways to increase WSIN adoption such as providing technical assistance or offering financing or loan guarantees.

$\mathrm{T}$ he development and worldwide distribution of technologies associated with crops, irrigation infrastructures, hybridized seeds, and synthetic fertilizers, pesticides, and fungicides occurred during the "green revolution" (1940s to the 1970s). Combined with a shift to large-scale agricultural production and improved farm management techniques, these new technologies dramatically increased crop yields and world food supplies (Evenson and Golin, 2003; Paarlberg, 2010).

This paper is part of a series of manuscripts describing the research and development completed by the SCRI-MINDS (Managing Irrigation and Nutrition through Distributed Sensing) project. The authors gratefully acknowledge funding and support from the USDA-NIFA Specialty Crops Research Initiative; Award \#2009-51181-05768.

${ }^{1}$ University of Maryland, Plant Science and Landscape Architecture, 2125D Plant Science Bldg., College Park, MD 20742

${ }^{2}$ University of Maryland, Center for Environmental Science, Chesapeake Biological Laboratory, Solomons, MD 20688

${ }^{3}$ Corresponding author. E-mail: jcmajsz@umd.edu.
These shifts, however, perpetuated agricultural practices that use significant amounts of water and energy, and involve applications of fertilizers and chemicals that have been determined to have significant adverse environmental impacts (Pingali, 2012). Although the development and application of technologies that increased food production generated significant positive economic returns to land owners, farmers, and agribusinesses, these intensified production systems also led to environmental degradation of soil and waterways, and generated problems that continue to persist today. Making agriculture more sustainable will be more difficult to implement since this usually involves costs that are not offset by expected increases in revenues (Behe et al., 2012).

New information-based technologies, such as WSIN have the potential to generate enough positive economic returns to warrant voluntary grower adoption, resulting in production systems that have lower environmental impacts (Belayneh et al., 2013; Lichtenberg et al., 2013). WSIN involve a fusion of soil/soilless moisture sensor networks, specialized hardware/software interfaces, and decision-support tools that have many potential applications. In ornamental crop applications, they have been shown to allow more efficient and precise "water on demand" irrigation decisions (Burnett and van Iersel, 2008; Nemali and van Iersel, 2006; Scoggins and van Iersel, 2006). Direct private benefits (e.g., economic returns on investment) will have the most influence on how widespread this technology is adopted in ornamental crop production. Environmental benefits, however, are also likely to affect rates of WSIN adoption in ornamental and other specialty crop applications and, potentially, in broader agricultural applications. Rates and levels of WSIN adoption, and associated private and environmental benefits, will also depend on other factors relating to growers access to information, risk tolerance, and the availability of technological advice and financing (Feder et al., 1985; Sunding and Zilberman, 2001).

\section{Basis of WSIN environmental benefits}

Water sensing technologies have been used for decades to monitor irrigation in conventional agricultural crop production, especially where water is scarce or costly, yield or quality are highly dependent on proper irrigation, or runoff is heavily regulated (van Iersel et al., 2013). In the past 10 years, advances in new types of sensor technologies, decision-support

\begin{tabular}{llll}
\hline $\begin{array}{l}\text { Units } \\
\begin{array}{l}\text { To convert U.S. to SI, } \\
\text { multiply by }\end{array}\end{array}$ & U.S. unit & SI unit & $\begin{array}{l}\text { To convert SI to U.S., } \\
\text { multiply by }\end{array}$ \\
\hline 0.4047 & $\mathrm{acre}(\mathrm{s})$ & $\mathrm{ha}$ & 2.4711 \\
3.7854 & $\mathrm{gal}$ & $\mathrm{L}$ & 0.2642 \\
9.3540 & $\mathrm{gal} / \mathrm{acre}$ & $\mathrm{L} \cdot \mathrm{ha}^{-1}$ & 0.1069 \\
0.4536 & $\mathrm{lb}$ & $\mathrm{kg}$ & 2.2046 \\
1.1209 & $\mathrm{lb} / \mathrm{acre}$ & $\mathrm{kg} \cdot \mathrm{ha}^{-1}$ & 0.8922 \\
0.9072 & ton(s) & $\mathrm{Mg}$ & 1.1023
\end{tabular}

Hortlechnology · December $201323(6)$ 
tools, and automated irrigation control technologies have significantly improved the efficiency and reliability of these technologies and, at the same time, decreased purchase and operating costs (Lea-Cox, 2012; Lea-Cox and Belayneh, 2012; Lichtenberg et al., 2013).

The frequency of irrigation management decisions in intensive agricultural production systems, such as ornamental production, varies greatly. Irrigation decisions are dependent on physical constraints and infrastructure, the type of irrigation system being used (e.g., drip vs. spray), geographic region, and the types of species being grown. Managers of field operations, for example, may make daily or weekly irrigation decisions, while managers of greenhouse operations may make hourly decisions about whether and how much to irrigate. At each decision point, regardless of the operation, there are two options, irrigate or not irrigate. The option that is selected at each decision point has cumulative effects on water and energy use, crop growth, fertilizer uptake, water and nutrient discharges, and carbon and other air emissions. Repeatedly making the correct irrigation decision will optimize plant growth, improve profits, and reduce environmental impacts. Routinely making incorrect irrigation decisions, most typically irrigating when it is not necessary, can lead to slow growth, disease problems, fertilizer leaching, reduced profitability, and a host of other economic and environmental problems. The economic and environmental payoffs from using WSIN are based on their capacity to help growers routinely make correct irrigation decisions.

\section{Pattern of WSIN environmental benefit development}

The typical sequence of development in complex applications of new technologies, such as no-till farming or microprocessing, is depicted in Fig. I based on the technology development curve created by King (1992). For technologies whose benefits are clearly demonstrated in early trials (Stages 8 and 9), rates of adoption and the accrual of related benefits during Stage 10 usually follow an S-shaped path, as illustrated in Fig. I (National Research Council, 1997). As the technology becomes more well

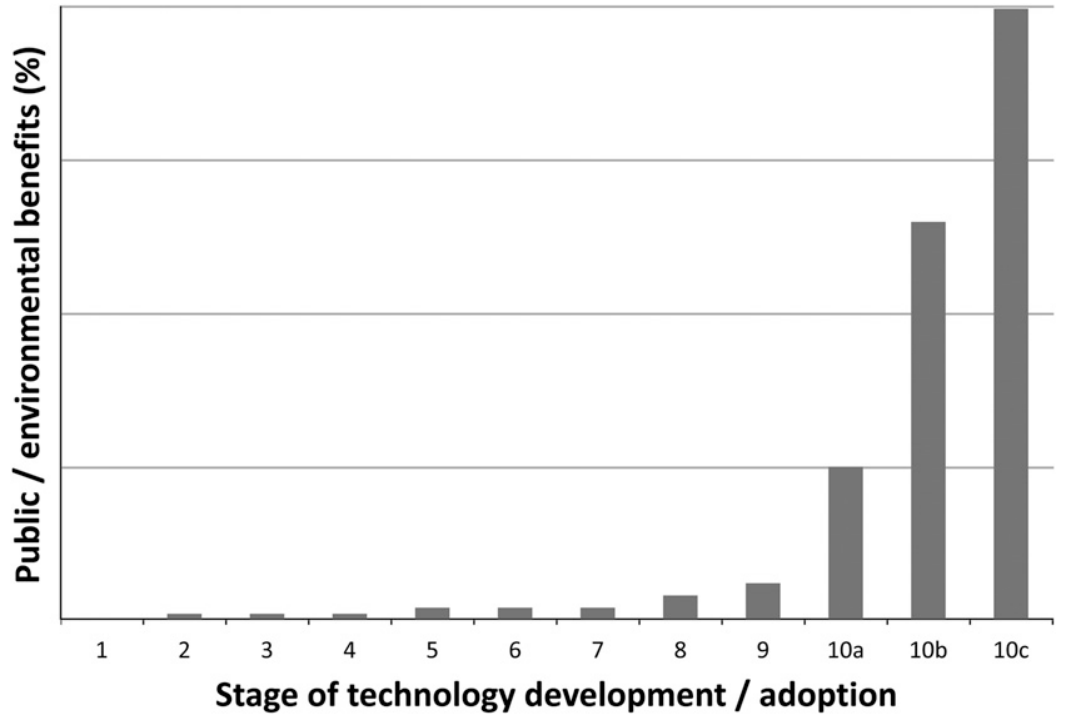

Fig. 1. Theoretical environmental benefits that can be gained from emerging wireless sensor irrigation network technologies (modified from National Research Council, 1997). Stages of technology development/adoption are 1) proof of concept, 2) basic science and engineering, 3) experimentation, 4) initial implementation, 5) method comparison, 6) method standardization, 7) equipment development, 8) limited early adoption, 9) industrial development, 10a) initial adoption, 10b) diffusion, 10c) final adoption.

known, rates of adoption and diffusion increase until the majority of those who stand to benefit from the technology have adopted it, and benefits then level off.

Based on the status of the WSIN demonstration projects illustrated by Chappell et al. (2013) and Belayneh et al. (2013), sensor-based irrigation networks are currently entering Stage 9 in ornamental production. A few early adopters are employing WSIN for more than just monitoring purposes, but adoption rates are still too low for any significant private or environmental benefits to have been achieved. One goal of this project is to help move this technology forward through Stage 9 to Stage 10 by highlighting the potential of WSIN to improve operational efficiency, generate economic returns, and reduce environmental impacts in ornamental production.

At this stage of WSIN development, three things about Fig. 1 are important. First, the environmental benefits that will result from WSIN technologies during Stage 10 will depend on the rate or speed of adoption (the slope of the $S$ curve), and on the extent or ceiling of adoption (where the S curve levels out). Second, the rate and extent of adoption during Stage 10 will depend, to a large extent, on the availability of information about potential private benefits during Stage 9 as described in Lichtenberg et al. (2013) and Belayneh et al. (2013). Third, effective, low-cost strategies can be employed during Stage 9 to increase private as well as environmental benefits by promoting the adoption of beneficial technologies to launch Stage 10 (see below).

\section{Tracing multiple WSIN benefits}

The original goals of this project were to develop and test WSIN technologies and demonstrate their capacity to save water (an environmental benefit) and reduce water and water management costs to growers (private benefits). Early results and interviews with growers in the eastern and central United States, where water availability is high, indicated that water costs are a relatively small portion of overall operating costs (Belayneh et al., 2013), and that water savings alone would not provide enough incentive for many growers to shift to WSIN-based irrigation management. However, besides nominal cost savings associated with reduced water use, WSIN installations showed that soil moisture and other data resulted in significant reductions in input use, which produced significant revenue increases associated with improved crop growth and yields. 
These impacts of WSIN use should result in economic returns on investments high enough to expect relatively high adoption rates of this technology (Belayneh et al., 2013; Chappell et al., 2013; Lichtenberg et al., 2013).

Other articles in this series highlight project results that document the economic benefits provided by these systems (Belayneh et al., 2013; Chappell et al., 2013; Lichtenberg et al., 2013). These benefits result, in part, because WSIN provide quantitative volumetric water content in real time, an accurate way to schedule irrigation. Also, WSIN allow growers to store historical, quantitative information from past days and weeks to show trends, overlay weather information and data, and incorporate other information to improve water and nutrient management decisions. Combined, this information not only allows growers to improve practices where a WSIN is being used, but also translates that information to improve practices in other similar areas where a WSIN is not being used. The ability to access sensor information remotely (via website or smartphone) also reduces hours spent monitoring plants thus optimizing on-site staff time management. This article focuses on the public benefits of implementing WSIN technology in ornamental production operations across the United States.

\section{Materials and methods Measures of potential WSIN environmental benefits}

Adoption of WSIN technologies in ornamental or other specialty crop production has not yet reached the point where overall environmental benefits have been generated. The magnitudes of potential environmental benefits illustrated here are based on various assumed rates of WSIN adoption and estimates of baseline values and expected reductions in water use and air and water emissions derived from national datasets, projectrelated survey results, published data from other related studies, and our best professional judgment about WSIN applications.

REDUCtion In WATER USE. Estimates of regional water use for greenhouse operations were derived from the Horticultural Operations section of the U.S. Department of Agriculture (USDA) Census of Agriculture
Farm and Ranch Irrigation Survey [FRIS (USDA, 2010a)]. FRIS data are reported for "open field" operations only, and do not distinguish between container and field operations. We estimated water use in container and field operations by adjusting FRIS open field data using proportions extrapolated from Majsztrik (2011), which contained information base on site visits to operations in Maryland. As far as we are aware, there are no breakdowns of container and field acreage by state that are available for our analysis.

The project's research and demonstration projects have not resulted in estimates of how using WSIN would reduce water use in all types of ornamental crop production in all geographic regions. Based on preliminary work, however, it is reasonable to assume that average consumption of water by operations that adopt WSIN would decline by $\approx 50 \%$. Initially, this rate of water use reduction was used with estimates of current water use by growers in various geographic regions and assumed endpoint adoption rates of $25 \%, 50 \%$, $75 \%$, and $100 \%$ to project potential regional reductions in water use. No attempt was made to estimate the rate or speed of adoption (the slope of the curve in Fig. 1). Other assumptions regarding percent reductions in water use and regional adoption rates were used to test the sensitivity of results. It is possible that water savings from the adoption of WSIN technology by growers who are water limited, but not land limited, would result in an increase in acreage of ornamental production rather than water use saving. The analysis and results presented here are based on the assumption that no additional land is used for ornamental production.

Potential regional reductions in water use in ornamental crop production were estimated using the formula $W_{j}^{k}=G_{j}^{k} \times D \times O_{j}^{k}$, where $W$ is the annual reduction in water use $(\mathrm{L})$ associated with the use of WSIN for operation type $j$ in region $k$. W is equal to $G$, the average number of liters used annually per operation type $j$ in region $k$, times $D$, the assumed percent reduction in water use associated with using WSIN, times $O$, the number of operations of type $j$ in region $k$.

Table 1 shows the potential magnitude of water savings associated with the adoption of WSIN technology in each geographical region. Reductions in water use are most notable in the Pacific region where baseline water usage is greatest. Assuming an average family of four consumes $\approx 1500 \mathrm{~L}$ of water per day [U.S. Environmental Protection Agency (EPA), 2013a], the average U.S. household uses $\approx 550,000 \mathrm{~L}$ of water annually. Nationwide, water savings associated with $50 \%$ adoption of WSIN technology in ornamental operations are estimated to be $\approx 223$ billion liters, which is equivalent to the annual water usage of $\approx 403,000$ households.

REDUCTION IN GREENHOUSE GAS EMISSIONS. For the purposes of this analysis, reductions in regional greenhouse gas emissions associated with the use of WSIN were estimated only on the basis of expected decreases in the amount of energy needed to pump water for irrigation. There may be other potential energy efficiencies associated with the use of this technology (e.g., reduced need for above-ground movement of water). We limited our analysis to the main benefits associated with reduced pumping volume from WSIN to be conservative in our estimates.

Estimates of regional energy use for pumping irrigation water were calculated using data on average regional well characteristics from FRIS data. The energy required to pump an acre-inch of water, in terms of diesel fuel consumed, is a function of the pumping lift (i.e., the distance from the depth of the well drawdown to the discharge point) and the pressure at the pump discharge (Martin et al., 2011). The FRIS data also contain state-scale information on the types of fuel used to power wells, so relative use of diesel, gasoline, electricity, natural gas, and propane was calculated at the regional scale, and standard conversions from diesel to other fuel types were used to calculate the quantity of each fuel type needed to pump a hectare-meter of water, given regional well characteristics. Values for the equivalency of each of the energy sources and the quantity of carbon dioxide $\left(\mathrm{CO}_{2}\right)$ emitted as they are consumed were used to convert the quantities of fuel to megagrams of $\mathrm{CO}_{2}$ emissions (U.S. EPA, 2013b).

The number of liters of water applied per hectare of greenhouse 
operations was derived from the Horticultural Operations section of the USDA Census of Agriculture FRIS (USDA, 2010a). Water use in container and field operations were estimated by adjusting FRIS open field data using proportions derived from Majsztrik (2011), as detailed above. Reductions in $\mathrm{CO}_{2}$ emissions were estimated for each region by adjusting the number of liters applied per hectare for each operation type by an assumed decrease in water consumption associated with the use of WSIN ( $50 \%$ for this analysis). This reduction in water use per hectare was converted to hectaremeters and then converted to reduction in megagrams of $\mathrm{CO}_{2}$ emissions per hectare. Total regional reduction in $\mathrm{CO}_{2}$ emissions was calculated using the formula $C_{j}^{k}=\frac{A_{j}^{k}}{279.119} \times D \times$ $E^{k} \times B_{j}^{k} \times O_{j}^{k}$, where $C$ is the annual reduction in megagrams of $\mathrm{CO}_{2}$ emissions associated with the use of WSIN for operation type $j$ in region $k$. $C$ is equal to $A$, the average number of liters applied per hectare annually in operation type $j$ in region $k$ converted to hectare-meters, times $D$, the assumed percent reduction in water use associated with using WSIN, times $E$, the weighted sum of megagrams $\mathrm{CO}_{2}$ emissions for all energy sources in region $k$, times $B$, the average number of hectares per operation of type $j$ in region $k$, times $O$, the number of operations of type $j$ in region $k$.

The potential magnitude of greenhouse gas emission reduction associated with the adoption of WSIN technology is illustrated in Table 2 . Reductions in greenhouse gas emissions are most notable in the Pacific region where water usage, and therefore pumping for irrigation, is greatest. The nationwide reduction in $\mathrm{CO}_{2}$ emissions associated with a $50 \%$ adoption rate of this technology in ornamental crop production is estimated to be $36,232 \mathrm{Mg}$. Assuming an average of $4.8 \mathrm{Mg}$ of $\mathrm{CO}_{2}$ emissions per motor vehicle per year (U.S. EPA, 2013b), this is equivalent to eliminating the annual $\mathrm{CO}_{2}$ emissions of $\approx 7500$ cars.

REDUCTION IN NUTRIENT RUNOFF. Reductions in nutrient runoff associated with the use of WSIN technology were estimated by comparing baseline and "with WSIN" conditions. Runoff estimates for baseline conditions
Table 1. Annual potential regional reduction in water use through the adoption of wireless sensor irrigation networks (WSIN) for ornamental production. Water reductions are reported using a $50 \%$ and $100 \%$ adoption scenario, and assuming a $50 \%$ reduction in water use once WSIN are adopted at operation.

\begin{tabular}{llrr}
\hline & & \multicolumn{2}{c}{$\begin{array}{c}\text { Annul reduction in water } \\
\text { use (million L) }\end{array}$} \\
\cline { 2 - 4 } Region & Operation type & $\mathbf{5 0 \%}$ adoption & $\mathbf{1 0 0 \%}$ adoption \\
\hline Appalachian & Greenhouse & $1,243.6$ & $2,487.2$ \\
& Container & $6,364.3$ & $12,728.7$ \\
Midwest & Field & $3,788.9$ & $7,577.7$ \\
& Greenhouse & $2,347.6$ & $4,695.2$ \\
Mountain/South-central/ & Container & $5,893.0$ & $11,786.1$ \\
Great Plains & Field & $3,508.3$ & $7,016.6$ \\
& Greenhouse & $3,813.3$ & $7,626.7$ \\
Northeast & Container & $18,133.2$ & $36,266.4$ \\
& Field & $30,459.2$ & $60,918.4$ \\
Pacific & Greenhouse & $1,650.0$ & $3,300.0$ \\
& Container & $3,594.7$ & $7,189.5$ \\
\multirow{2}{*}{ Southeast } & Field & $6,038.3$ & $12,076.5$ \\
& Greenhouse & $5,390.5$ & $10,781.0$ \\
& Container & $50,480.6$ & $100,961.2$ \\
All regions & Field & $30,052.5$ & $60,105.0$ \\
& Greenhouse & $9,941.2$ & $19,882.5$ \\
& Container & $24,977.0$ & $49,954.0$ \\
& Field & $14,869.5$ & $29,739.0$ \\
& Greenhouse & $24,386.3$ & $48,772.7$ \\
& Container & $109,443.0$ & $218,885.9$ \\
& Field & $88,716.6$ & $177,433.3$ \\
& Total & $\mathbf{2 2 2 , 5 4 5 . 9}$ & $\mathbf{4 4 5 , 0 9 1 . 9}$ \\
\hline
\end{tabular}

${ }^{2} \mathrm{~L} \mathrm{~L}=0.2642$ gal.

Table 2. Annual potential regional reduction in carbon dioxide $\left(\mathrm{CO}_{2}\right)$ emissions by using wireless sensor irrigation networks. Annual $\mathrm{CO}_{2}$ reductions are based on a $50 \%$ reduction in pumping volumes, for $50 \%$ and $100 \%$ of ornamental operations.

\begin{tabular}{|c|c|c|c|}
\hline \multirow[b]{2}{*}{ Region } & \multirow[b]{2}{*}{ Operation type } & \multicolumn{2}{|c|}{$\begin{array}{l}\text { Annual reduction in } \\
\mathrm{CO}_{2} \text { emissions }(\mathrm{Mg})^{\mathrm{z}}\end{array}$} \\
\hline & & $50 \%$ adoption & $100 \%$ adoption \\
\hline \multirow[t]{3}{*}{ Appalachian } & Greenhouse & 208 & 415 \\
\hline & Container & 1,062 & 2,124 \\
\hline & Field & 632 & 1,265 \\
\hline \multirow{3}{*}{ Midwest } & Greenhouse & 311 & 623 \\
\hline & Container & 781 & 1,563 \\
\hline & Field & 40 & 80 \\
\hline \multirow{3}{*}{$\begin{array}{l}\text { Mountain/South-central/ } \\
\text { Great Plains }\end{array}$} & Greenhouse & 560 & 1,119 \\
\hline & Container & 4,469 & 8,938 \\
\hline & Field & 2,661 & 5,321 \\
\hline \multirow[t]{3}{*}{ Northeast } & Greenhouse & 319 & 639 \\
\hline & Container & 1,169 & 2,338 \\
\hline & Field & 696 & 1,392 \\
\hline \multirow[t]{3}{*}{ Pacific } & Greenhouse & 933 & 1,866 \\
\hline & Container & 8,738 & 17,475 \\
\hline & Field & 5,202 & 10,404 \\
\hline \multirow[t]{3}{*}{ Southeast } & Greenhouse & 1,688 & 3,375 \\
\hline & Container & 4,240 & 8,480 \\
\hline & Field & 2,524 & 5,048 \\
\hline \multirow[t]{4}{*}{ All regions } & Greenhouse & 4,018 & 8,037 \\
\hline & Container & 20,459 & 40,918 \\
\hline & Field & 11,755 & 23,509 \\
\hline & Total & 36,232 & 72,465 \\
\hline
\end{tabular}

${ }^{2} 1 \mathrm{Mg}=1.1023$ ton. 
were calculated by multiplying nitrogen $(\mathrm{N})$ and phosphorus $(\mathrm{P})$ application rates on a variety of crops in greenhouse, container and field operations (Majsztrik, 2011) by the estimated runoff rate for each operation type based on the output of models developed by Majsztrik (2011). Briefly, the models used average $\mathrm{N}$ and $\mathrm{P}$ rates applied by greenhouse, container, and field growers in Maryland to derive baseline runoff rates for the scenarios reported here.

Two scenarios were created for "with WSIN" conditions: a conservative adoption scenario (Table 3 ) and an optimistic adoption scenario (Table 4). Assumed reductions in application rates for "with WSIN" conditions for both scenarios were estimated using results from Chappell et al. (2013), Belayneh et al. (2013), and Lichtenberg et al. (2013) and our best professional judgment for larger scale reductions in nutrient application and runoff (Tables 3 and 4 ).

Overall regional reduction in nutrient runoff was calculated by multiplying the decrease in $\mathrm{N}$ and $P$ runoff (kilograms per hectare) for each crop/operation type combination by the regional proportion of the overall production that each crop and operation-type combination represents. For each operation type, this value was then multiplied by the regional average size of the operation type and the number of operations in each operation type in the region according to the following equations

$N_{j}^{k}=\sum_{i}^{j} X_{i j}^{k} \times Z_{i j}^{k} \times H_{j}^{k} \times O_{j}^{k}$ and
$P_{j}^{k}=\sum_{i}^{j} Y_{i j}^{k} \times Z_{i j}^{k} \times H_{j}^{k} \times O_{j}^{k}$, where

$\mathrm{N}$ is the annual reduction in kilograms of $\mathrm{N}$ runoff associated with the use of WSIN for operation type $j$ in region $k$, and $P$ is the annual reduction in kilograms of $P$ runoff associated with the use of WSIN for operation type $j$ in region $k$. Nor $P$ is equal to the sum of $X$, the estimated reduction in $\mathrm{N}$ runoff (kilograms per hectare) associated with the use of WSIN for crop type $i$ in operation type $j$ in region $k$ or $\Upsilon$, the estimated reduction in $P$ runoff (kilograms per hectare) associated with the use of WSIN for crop type $i$ in operation type $j$ in region $k$, times $Z$, the proportion of crop type $i$ and operation type $j$ in region $k$, times $H$, the average number of hectares per operation of type $j$ in region $k$, times $O$, the number of operations of type $j$ in region $k$.

Table 5 shows the potential regional and national reductions in $\mathrm{N}$ and $\mathrm{P}$ discharges from horticultural operations resulting from $50 \%$ and $100 \%$ WSIN adoption rates. Nationwide reductions in annual nutrient discharges associated with a $50 \%$ adoption of WSIN are estimated to range from 282,000 to $603,000 \mathrm{~kg}$ for $\mathrm{N}$ and from 182,000 to $378,000 \mathrm{~kg}$ for $P$. Nitrogen and especially $P$ values are likely to be underestimated in Table 5 because the baseline values that were used were based on data related to ornamental growers in Maryland, which operate under relatively strict nutrient discharge limits to reduce environmental impacts to the Chesapeake Bay. Many

Table 3. Conservative scenario for adjusting nutrient application and runoff rates with the use of wireless sensor irrigation networks (WSIN) compared with currently baseline values without WSIN.

\begin{tabular}{llc}
\hline & \multicolumn{2}{c}{ With WSIN } \\
\cline { 2 - 3 } Operation type & \multicolumn{1}{c}{ Application rate } & Runoff rate \\
\hline Greenhouse & $25 \%$ less than baseline & $25 \%$ less than baseline \\
Container & Unchanged from baseline & $25 \%$ less than baseline \\
Field & Unchanged from baseline & $25 \%$ less than baseline \\
\hline
\end{tabular}

Table 4. Optimistic scenario for adjusting nutrient application and runoff rates with the use of wireless sensor irrigation networks (WSIN) compared with currently baseline values without WSIN.

\begin{tabular}{llc}
\hline & \multicolumn{2}{c}{ With WSIN } \\
\cline { 2 - 3 } Operation type & \multicolumn{1}{c}{ Application rate } & Runoff rate \\
\hline Greenhouse & $40 \%$ less than baseline & $40 \%$ less than baseline \\
Container & $25 \%$ less than baseline & $40 \%$ less than baseline \\
Field & Unchanged from baseline & $40 \%$ less than baseline \\
\hline
\end{tabular}

Maryland growers have already implemented a number of BMPs to reduce nutrient and sediment runoff that are not typical to other regions of the country where legislation has not been as strong (Majsztrik and Lea-Cox, 2013). This is particularly true for $P$ runoff from field operations since it was found that $100 \%$ of Maryland field operations that were sampled had inrow and end-of-row grass buffer strips which reduce P runoff(Majsztrik, 2011), whereas elsewhere in the country, particularly in the west, ornamental production occurs on bare ground, making $\mathrm{P}$ movement much more likely. For this reason, we are not reporting $\mathrm{P}$ runoff reduction for field operations because the modeled scenarios based on the data currently available, which are for Maryland, are not likely to be representative of the country. We are also likely to be underestimating $\mathrm{N}$ reductions from WSIN in field operations for the same reason, but we include estimates of $\mathrm{N}$ reductions in Table 5 . Future work will focus on estimating WSIN-based $\mathrm{N}$ and $\mathrm{P}$ reductions in field operations nationwide. Greenhouse and container production practices across the country are likely to be similar to Maryland so the values reported in Table 5 for those WSIN applications are likely to be representative.

ENVIRONMENTAL BENEFITS PER OPERATION. To provide a basis for growers and others to estimate potential environmental benefits of WSIN in commercial operations of different types and sizes, we assumed a linear relationship between output and water use, carbon emissions, and nutrient emissions in each operation type. For each operation type, we then estimated potential benefits of WSIN in three categories: reduced water use, carbon emissions, and nutrient discharges per million dollars of output. This standard approach allows these benefits to be estimated using generally available information about the size and type of operations rather than often-unavailable operationscale information about water and energy use or air and water emissions. To arrive at these average values, we estimated total business sales for each operation type using regional sales data for horticultural operations from the USDA Census of Agriculture: Census of Horticultural Specialties (USDA, 2010b) and then adjusted for each operation type according to 
Table 5. Potential reductions in annual nitrogen $(N)$ and phosphorus $(P)$ runoff for ornamental production with adoption of wireless sensor irrigation networks using two different scenarios (conservative and optimistic) with two different adoption rates $(50 \%$ and $100 \%)$. Reductions in nutrient emissions are based on two scenarios. The conservative scenario reduces runoff rates by $\mathbf{2 5 \%}$ for greenhouse, container, and field operations, and application rates by $\mathbf{2 5} \%, \mathbf{0} \%$, and $\mathbf{0 \%}$, respectively (see Table 3 ). The optimistic scenario reduces runoff rates by $40 \%$ for greenhouse, container, and field operations, and application rates by $40 \%, 25 \%$, and $0 \%$, respectively (see Table 4). Phosphorus values are not reported for field operations because reliable data for $P$ runoff could not be obtained outside of Maryland.

\begin{tabular}{|c|c|c|c|c|c|c|c|c|c|}
\hline \multirow{3}{*}{\multicolumn{2}{|c|}{$\begin{array}{c}\text { Operation } \\
\text { type }\end{array}$}} & \multicolumn{4}{|c|}{ Conservative scenario } & \multicolumn{4}{|c|}{ Optimistic scenario } \\
\hline & & \multicolumn{2}{|c|}{$50 \%$ adoption } & \multicolumn{2}{|c|}{$100 \%$ adoption } & \multicolumn{2}{|c|}{$50 \%$ adoption } & \multicolumn{2}{|c|}{$100 \%$ adoption } \\
\hline & & $\begin{array}{c}\mathrm{N} \\
\text { reduction } \\
(\mathrm{kg})^{\mathrm{z}}\end{array}$ & $\begin{array}{c}\mathbf{P} \\
\begin{array}{c}\text { reduction } \\
(\mathrm{kg})\end{array} \\
\end{array}$ & $\begin{array}{c}\mathrm{N} \\
\text { reduction } \\
(\mathrm{kg})\end{array}$ & $\begin{array}{c}\mathbf{P} \\
\begin{array}{c}\text { reduction } \\
(\mathrm{kg})\end{array} \\
\end{array}$ & $\begin{array}{c}\mathrm{N} \\
\text { reduction } \\
(\mathrm{kg})\end{array}$ & $\begin{array}{c}\mathbf{P} \\
\begin{array}{c}\text { reduction } \\
(\mathrm{kg})\end{array} \\
\end{array}$ & $\begin{array}{c}\mathrm{N} \\
\text { reduction } \\
(\mathrm{kg})\end{array}$ & $\begin{array}{c}\mathrm{P} \\
\text { reduction } \\
(\mathrm{kg})\end{array}$ \\
\hline \multirow[t]{2}{*}{ Appalachian } & Greenhouse & 766 & 925 & 1,533 & 1,850 & 1,121 & 1,121 & 2,242 & 2,242 \\
\hline & Container & 18,260 & 11,231 & 36,520 & 22,462 & 40,172 & 24,709 & 80,344 & 49,417 \\
\hline & Container & 30,041 & 17,949 & 60,082 & 35,897 & 66,090 & 39,487 & 132,180 & 78,974 \\
\hline & Field & 607 & - & 1,214 & - & 972 & - & 1,943 & - \\
\hline \multirow{3}{*}{$\begin{array}{l}\text { Mountain/ } \\
\text { South-central } \\
\text { Great Plains }\end{array}$} & Greenhouse & 2,628 & 3,194 & 5,256 & 6,388 & 3,845 & 4,673 & 7,689 & 9,345 \\
\hline & Container & 63,736 & 39,794 & 127,471 & 79,588 & 140,218 & 87,547 & 280,436 & 175,093 \\
\hline & Field & 733 & - & 1,467 & - & 1,173 & - & 2,347 & - \\
\hline Northeast & Greenhouse & 1,019 & 1,415 & 2,037 & 2,830 & 1,490 & 2,070 & 2,980 & 4,139 \\
\hline & Container & 32,692 & 21,288 & 65,384 & 42,576 & 71,923 & 46,834 & 143,845 & 93,668 \\
\hline & Field & 723 & - & 1,445 & 一 & 1,156 & - & 2,313 & - \\
\hline \multirow[t]{3}{*}{ Southeast } & Greenhouse & 7,829 & 9,648 & 15,659 & 19,297 & 11,453 & 14,114 & 22,907 & 28,228 \\
\hline & Container & 69,608 & 37,553 & 139,215 & 75,107 & 153,137 & 82,618 & 306,273 & 165,235 \\
\hline & Field & 657 & - & 1,313 & - & 1,051 & - & 2,101 & - \\
\hline \multirow[t]{4}{*}{ All regions } & Greenhouse & 21,884 & 28,713 & 43,768 & 57,425 & 32,013 & 41,770 & 64,026 & 83,541 \\
\hline & Container & 257,412 & 153,057 & 514,824 & 306,114 & 566,307 & 336,725 & $1,132,613$ & 673,450 \\
\hline & Field & 3,128 & - & 6,257 & - & 5,005 & - & 10,011 & - \\
\hline & Total & 282,424 & 181,769 & 564,849 & 363,539 & 603,325 & 378,495 & $1,206,650$ & 756,991 \\
\hline
\end{tabular}

${ }^{\mathrm{z}} 1 \mathrm{~kg}=2.2046 \mathrm{lb}$.

the proportions of operations in each operation type derived from a survey of ornamental plant producers that was completed as part of this project (Majsztrik et al., 2013).

Reductions per million dollars output in each environmental benefit category were calculated using the equation $T_{j}^{k l}=R_{j}^{k l} \times O_{j}^{k} \times \frac{\$ 1,000,000}{S_{j}^{k}}$, where

$T$ is the magnitude of environmental benefit $l$ for operation type $j$ in region $k$ per million dollars output. $T$ is equal to $R$, the reduction in consumption, emissions, or runoff $(l)$ for operation type $j$ in region $k$, times $O$ is the number of operations of type $j$ in region $k$, divided by $S$, the total sales of operation type $j$ in region $k$.

The average magnitudes of potential environmental benefits per million dollars of output for each operation type per region, and for the United States, are presented in Table 6 . The magnitude of potential environmental benefits per region, and overall for the United States, are presented in Table 7.

\section{Results and discussion}

MONETIZING POTENTIAL ENVIRONMENTAL BENEFITS: CHESAPEAKE BAY REGION ILLUSTRATION. A number of regions such as Florida, California and the Chesapeake Bay are implementing total maximum daily load (TMDL) regulations that limit the amount of certain pollutants that can be discharged into receiving waters. The cost and effectiveness of various agricultural and urban BMPs to control runoff and the prices of nutrient discharge offset credits that are emerging in various nutrient discharge trading programs provide a sense of what people are paying to reduce nutrient runoff by $1 \mathrm{~kg}$, or what they are willing to pay for a $1-\mathrm{kg}$ nutrient discharge offset. Combining cost/price information with the results of estimated WSIN-based reductions in discharges from ornamental crop production provides a preliminary basis for monetizing nutrient-related WSIN benefits. For illustration purposes, we apply basic BMP cost information to the region that makes up the Chesapeake Bay watershed, which sets limits on $\mathrm{N}, \mathrm{P}$, and sediment entering receiving waters.

Table 8 shows the potential reduction in $\mathrm{N}$ and $\mathrm{P}$ runoff in the Chesapeake Bay watershed for different adoption rates of WSIN technology, according to the assumptions described above with respect to the "optimistic scenario." Preliminary BMP cost information and early prices emerging from water quality trading in the Chesapeake Bay region suggest that the economic value of reductions in nutrient discharge can be estimated at a current rate of roughly $\$ 40$ per pound of $\mathrm{N}$ and $\$ 80$ per pound of $\mathrm{P}$ (Majsztrik and Lea-Cox, 2013).

Our preliminary analysis of potential nutrient runoff reduction in 







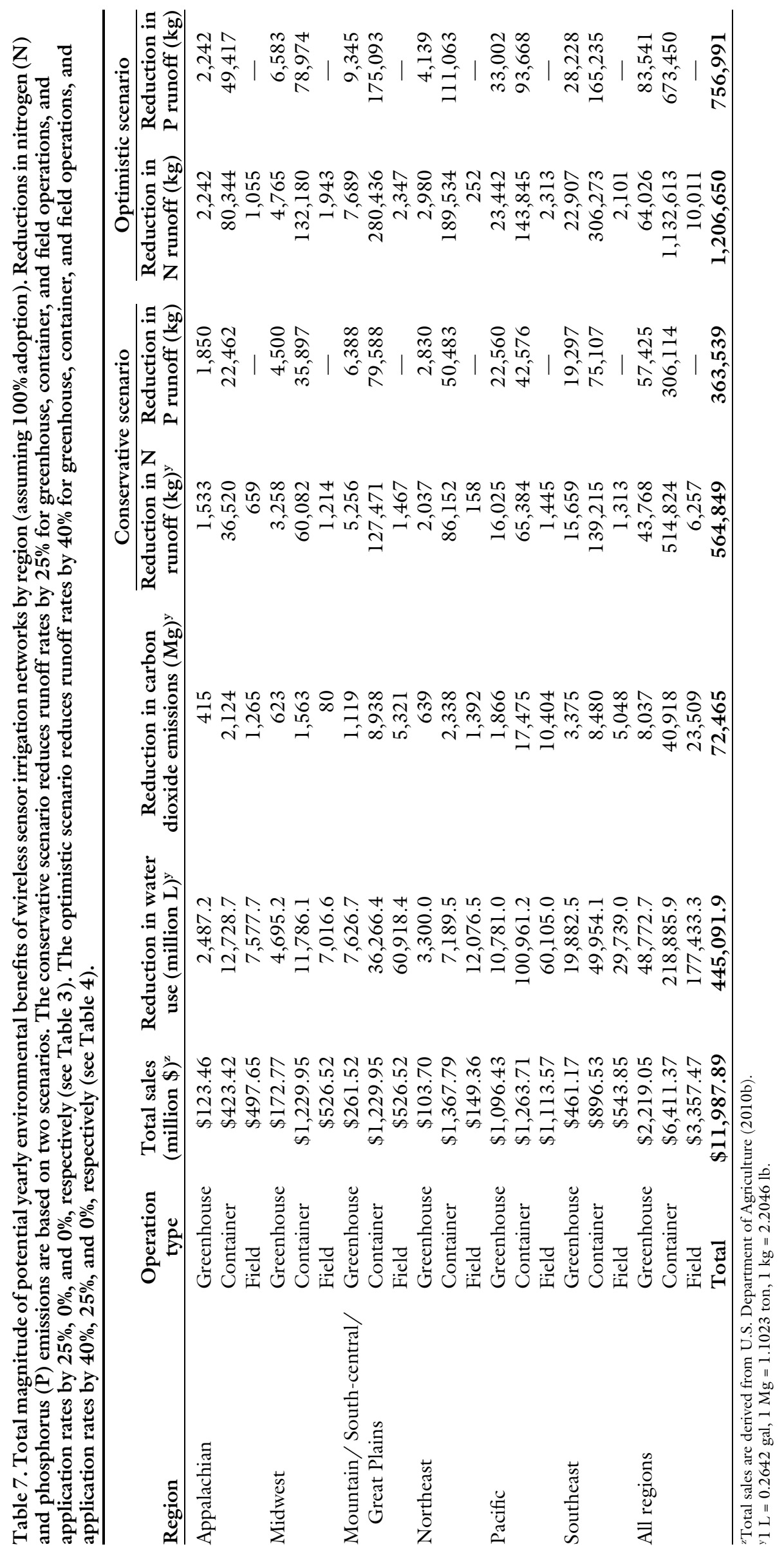


Table 8. Reductions in resource use and emissions in the Chesapeake Bay Watershed associated with the use of wireless sensor irrigation network technology, assuming various adoption rates. Reductions in water use and carbon dioxide $\left(\mathrm{CO}_{2}\right)$ emissions are based on a $50 \%$ reduction in the application of irrigation water. Reductions in nutrient emissions are based on the optimistic scenario, which reduces runoff rates by $\mathbf{4 0 \%}$ for greenhouse, container, and field operations, and application rates by $40 \%, 25 \%$, and $0 \%$, respectively (see Table 4 ).

\begin{tabular}{lccc}
\hline $\begin{array}{l}\text { Chesapeake watershed } \\
\text { reductions in: }\end{array}$ & $\begin{array}{c}\mathbf{2 5 \%} \text { adoption } \\
\text { rate }\end{array}$ & $\begin{array}{c}\mathbf{5 0 \%} \text { adoption } \\
\text { rate }\end{array}$ & $\begin{array}{c}\mathbf{1 0 0 \%} \text { adoption } \\
\text { rate }\end{array}$ \\
\hline Water use (million $\mathrm{L})^{\mathrm{z}}$ & $3,246.5$ & $6,493.0$ & $12,986.0$ \\
$\mathrm{CO}_{2}$ emissions $(\mathrm{Mg})^{\mathrm{z}}$ & 560 & 1,119 & 2,239 \\
Nitrogen discharge $(\mathrm{kg})^{\mathrm{z}}$ & 16,091 & 32,181 & 64,362 \\
Phosphorus discharge $(\mathrm{kg})$ & 9,533 & 19,067 & 38,133 \\
\hline
\end{tabular}

${ }^{\mathrm{z}} 1 \mathrm{~L}=0.2642 \mathrm{gal}, 1 \mathrm{Mg}=1.1023 \mathrm{ton}, 1 \mathrm{~kg}=2.2046 \mathrm{lb}$.

the Chesapeake Bay region suggests that a $50 \%$ adoption rate of WSIN technology would result in $\approx 32,000 \mathrm{~kg}$ less $\mathrm{N}$ and $\approx 19,000 \mathrm{~kg}$ less $\mathrm{P}$ being discharged into the Chesapeake Bay watershed, and with a $100 \%$ adoption rate $\approx 64,000 \mathrm{~kg}$ less $\mathrm{N}$ and $\approx 38,000 \mathrm{~kg}$ less $\mathrm{P}$ discharged. Generating this level of reduction using traditional BMPs and/or purchasing this amount of reduction as offsets would cost $\approx \$ 2.8$ to $\$ 5.7$ million for $\mathrm{N}$ reduction and $\approx \$ 3.4$ to $\$ 6.8$ million for $P$ reduction.

WSIN costs. Although this SCRI research has identified many potential benefits of WSIN that should encourage adoption, it has also identified some factors that could inhibit widespread adoption. Currently, the cost of a "starter" system, which includes all software, a base station to collect data from nodes, three nodes that collect data, and 15 sensors, is $\approx \$ 5000$. To expand an existing WSIN system, an operation would need to purchase additional nodes at a cost of $\approx \$ 1200$ each (for a node and five sensors). Economic analysis of WSIN installations under real-world conditions indicate that they typically have payback periods ranging from a month to a few years (Belayneh et al., 2013; Lichtenberg et al., 2013). Lack of access to capital, however, could limit the ability of some growers to invest in WSIN.

RECOMMENDATIONS FOR MAXIMIZING ENVIRONMENTAL BENEFITS FROM WSIN. Since environmental benefits realized from WSIN technologies will depend critically on adoption rates, this project has sought to develop intuitive and user-friendly WSIN that meets the needs of a large majority of potential end users (Kohanbash and Kantor, 2012; Kohanbash et al., 2013).
Research results have established that applications of WSIN in at least some situations generate significant private (economic) benefits to growers (Belayneh et al., 2013; Lichtenberg et al., 2013), and a national survey indicates that growers have positive perceptions of sensor networks (Majsztrik et al., 2013). To promote high rates of WSIN adoption, however, growers, business managers, consultants and researchers need to have access to information about how to install and gain the maximum benefit from WSIN technology. A dedicated website and knowledge center has been developed to disseminate project information and results, and inform people about how to use and maximize the benefits from this type of technology (LeaCox, 2013).

Other factors, beyond the scope of this project, will affect adoption rates for WSIN technologies and impact the environmental benefits outlined in this article. A well-defined support structure will likely be needed to reduce adoption barriers, and increase environmental benefits by making investing in WSIN more economically attractive and less risky to growers. For example, growers considering shifting to WSIN will initially need access to consultants, extension agents, or other growers who are familiar with WSIN technologies to help them design and calibrate systems for their specific applications. Also, assistance may be necessary to make WSIN technologies compatible with existing irrigation and computer infrastructure.

Even if various case-study results convince many growers that the payback period for installing WSIN is short and economic returns are high, the initial cost of acquiring and installing a WSIN and lack of access to financing to spread these initial costs out over multiple years could be significant barriers to adoption for some growers. It seems important, therefore, to determine how economies of scale in the production and installation of WSIN can be leveraged to promote lower WSIN prices and installation costs to stimulate higher adoption rates.

Because of the expected public (environmental) benefits associated with having these WSIN technologies adopted, it might make sense for government (e.g., USDA-National Resource Conservation Service) or nonprofit organizations to promote adoption by finding ways to help growers afford initial startup costs. Cost sharing through Cooperative Extension would be one way to reduce initial startup expenses of these systems. Regulatory reforms that involve stricter water use and water discharge restrictions, or increasing charges or fees related to water use and carbon and water emissions are also likely to increase WSIN adoption rates. Using WSIN not only to reduce water use and water and carbon emissions but to monitor and validate those reductions may also result in these reductions being more valuable in terms of generating marketable offsets or credits in various regional emission and water trading programs.

Although we have focused on the impact of WSIN to ornamental growers, WSIN technology also has the potential to generate benefits in a variety of other agricultural applications. Wireless sensor irrigation network applications that seem particularly promising include fruit and vegetable production, especially crops that are susceptible to fluctuating soil moisture levels, such as tomato (Solanum lycopersicum), peach (Prunus persica), and grape (Vitis vinifera).

Nonagricultural benefit PATHWAYs. As part of our project, some applications of WSIN technologies outside of agriculture are also being tested. The most fully developed of these applications involve using wireless sensor networks to monitor and validate the effectiveness of green roofs in achieving various environmental goals, and to better inform green roof design, especially with regard to plant selection for storm water remediation (Starry, 2013). Access to rooftops is often limited due 
to safety and liability concerns and most of the environmental benefits of green roofs are not observable on site. Using WSIN to generate monitoring data provides opportunities to both promote public awareness and validate the effectiveness of green roofs, particularly when sensor networks are scaled up to provide information on a watershed scale. This should result in green roofs being more widely adopted.

\section{Conclusions}

Wireless sensor-based irrigation networks have been shown to reduce the use of water, nutrients, pesticide, and other inputs in a variety of settings. The cost savings associated with reductions in input use, combined with observed improvements in crop yields and reduced production times generate significant private benefits (profits) to growers.

Potential regional and national environmental benefits associated with reductions in $\mathrm{N}, \mathrm{P}$, water, and $\mathrm{CO}_{2}$ emissions were demonstrated using a number of sources. These environmental benefits are particularly valuable in regions such as the Chesapeake Bay, where using WSIN to help meet TMDL nutrient emission restrictions can result in higher profits rather than higher costs. Current research indicates that the potential direct and indirect private and public economic and environmental benefits from high rates of WSIN technology adoption would be worth the cost.

Outside of ornamental crop production, the most immediate potential for WSIN technologies to generate environmental benefits involve other specialty crops (i.e., small fruit, tree fruit, nut, vegetable production). However, there are likely to be many other potential pathways of indirect and induced environmental benefits associated with WSIN applications inside and outside of agriculture that cannot be projected at this time. For example, WSIN may offer new opportunities for producing food crops more locally on less land than has been needed previously, thereby increasing local food security and increasing food quality. Such applications could therefore reduce transportation costs and emissions, and improve balance of trade by creating economic conditions that allow for increased domestic production of ornamental and food crops.
Several additional steps are needed to promote adoption of WSIN and achieve the potential benefits outlined in this article. Although WSIN were designed to be user-friendly, they do require people trained to use and maintain them. Also, to reduce risks and maximize economic returns from using WSIN, growers will need at least some basic training in the use of specialized software and, ideally, at least some convenient access to a consultant, online or phone help, an extension agent, or other growers who are familiar with WSIN systems. As with any new technology, there are some barriers to the adoption of WSIN in ornamental crop production that will need to be overcome. However, research to date on demonstration WSIN applications indicate that WSIN should generate positive economic returns to operations that choose to install them and environmental benefits that go beyond reductions in fresh water use.

\section{Literature cited}

Behe, B.K., B.L. Campbell, C.R. Hall, H. Khachatryan, J.H. Dennis, and C. Yue. 2012. Consumer preferences for local and sustainable plant production characteristics. HortScience 48:200-208.

Belayneh, B., J.D. Lea-Cox, and E. Lichtenberg. 2013. Benefits and costs of implementing sensor-controlled irrigation in a commercial pot-in-pot container nursery. HortTechnology (In press).

Burnett, S.E. and M.W. van Iersel. 2008. Morphology and irrigation efficiency of Gaura lindheimeri grown with capacitance sensor-controlled irrigation. HortScience 43:1555-1560.

Chappell, M., S.K. Dove, M.W. van Iersel, P.A. Thomas, and J. Ruter. 2013. Implementation of wireless sensor networks for irrigation control in three container nurseries. HortTechnology 23:747-753.

Evenson, R.E. and D. Golin. 2003. Assessing the impact of the green revolution, 1960 to 2000 . Science 300:758-762.

Feder, G., R. Just, and D. Zilberman. 1985. Adoption of agricultural innovations in developing countries: A survey. Econ. Dev. Cult. Change 33:255-298.

King, D. 1992. The economics of ecological restoration, p. 493-526. In: J. Duffield and K. Ward (eds.). Natural resource damage assessment: Law and economics. Wiley, New York, NY.

Kohanbash, D. and G. Kantor. 2012. Irrigation scheduling software development.
Irr. Assn. Annu. Conf., 2-6 Nov. 2012, Orlando, FL.

Kohanbash, D., G. Kantor, T. Martin, and L. Crawford. 2013. Wireless sensor network design for monitoring and irrigation control: User-centric hardware and software development. HortTechnology 23: 725-734.

Lea-Cox, J.D. 2012. Using wireless sensor networks for precision irrigation scheduling, p. 233-258. In: M. Kumar (ed.). Problems, perspectives and challenges of agricultural water management. 19 Sept. 2013. <http://www.intechopen.com/books/ problems-perspectives-and-challenges-ofagricultural-water-management/using-sensornetworks-for-precision-irrigation-control>.

Lea-Cox, J.D. 2013. Managing irrigation and nutrition via distributed sensing. 25 Sept. 2013. <www.smart-farms.net/home>

Lea-Cox, J.D. and B. Belayneh. 2012. Irrigation complexities-Using sensor networks for real-time scheduling in commercial horticultural operations. Irr. Assn. Annu. Conf., 2-6 Nov. 2012, Orlando, FL.

Lichtenberg, E., J. Majsztrik, and M. Saavoss. 2013. Profitability of sensorbased irrigation in greenhouse and nursery crops. HortTechnology 23:770-774.

Majsztrik, J. 2011. Modeling nitrogen, phosphorus and water dynamics in greenhouse and nursery production systems. Univ. Maryland, College Park, PhD Diss.

Majsztrik, J. and J.D. Lea-Cox. 2013. Water quality regulations in the Chesapeake Bay: Working to more precisely estimate nutrient loading rates and incentivize best management practices in the nursery and greenhouse industry. HortScience 48:1097-1102.

Majsztrik, J., E. Lichtenberg, and M. Saavoss. 2013. Ornamental grower perceptions of wireless irrigation sensor networks: Results from a national survey. HortTechnology 23:775-782.

Martin, D.L., T.W. Dorn, S.R. Melvin, A.J. Corr, and W.L. Kranz. 2011. Evaluating energy use for pumping irrigation water. Proc. 23rd Annu. Central Plains Irr. Conf., 21-23 Feb. 2011, Burlington, CO. p. 22-23.

National Research Council. 1997. Precision agriculture in the 21 st Century. $\mathrm{Na}$ tional Academy Press, Washington, DC.

Nemali, K.S. and M.W. van Iersel. 2006. An automated system for controlling drought stress and irrigation in potted plants. Sci. Hort. 110:292-297.

Paarlberg, R.L. 2010. Food politics: What everyone needs to know. Oxford Press, New York, NY. 
Pingali, P.L. 2012. Green revolution: Impacts, limits, and the path ahead. Proc. Natl. Acad. Sci. USA 109:12302-12308.

Scoggins, H.L. and M.W. van Iersel. 2006. In situ probes for measurement of electrical conductivity of soilless substrates: Effects of temperature and substrate moisture content. HortScience 41:210-214.

Starry, O. 2013. The comparative effects of three Sedum species on green roof stormwater retention. Univ. Maryland, College Park, PhD Diss.
Sunding, D. and D. Zilberman (eds.) 2001. The agricultural innovation process: Research and technology adoption in a changing agricultural sector. Handbook of agricultural economics. Vol. 1. Elsevier Science, Amsterdam, The Netherlands.

U.S. Department of Agriculture. 2010a. Farm and ranch irrigation survey (2008). U.S. Dept. Agr., Natl. Agr. Stat. Serv., Washington, DC.

U. S. Department of Agriculture. 2010b. 2007 Census of agriculture: Census of horticultural specialties (2009). Vol. 3 Special Studies Part 3. U.S. Dept. Agr., Washington, DC.
U.S. Environmental Protection Agency. 2013a. Indoor water use in the United States. 22 Sept. 2013. <http://www.epa. gov/WaterSense/pubs/indoor.html>.

U.S. Environmental Protection Agency. 2013 b. Greenhouse gas equivalencies calculator. 22 Sept. 2013. <http://www. epa.gov/cleanenergy/energyresources/ calculator.html\#results $>$.

van Iersel, M.W., M. Chappell, and J.D. Lea-Cox. 2013. Sensors for improved efficiency of irrigation in greenhouse and nursery production. HortTechnology 23:735-746. 